\title{
Efektivitas Pembangunan Rumah Risha, Rika dan Riko (3R) bagi Masyarakat Terdampak Gempa
}

\author{
"Kamsuta', Ekky Irawanto', Holifia vania Rahmawati', Baiq Harly Widayanti' \\ 1 Program Studi Perencanaan Wilayah dan Kota, Fakultas Teknik, Universitas Muhammadiyah Mataram, Kota Mataram \\ ${ }^{2}$ Program Studi Rekayasa Sipil, Fakultas Teknik, Universitas Muhammadiyah Mataram, Kota Mataram \\ *Email: kamasuta117@gmail.com
}

\begin{abstract}
INFO ARTIKEL
ABSTRAK

Riwayat Artikel:

Diterima: $29-04-2020$

Disetujui: 08-05-2020

\section{Kata Kunci:}

Penyediaan air minum, Keberlanjutan, Modal manusia, Modal sosial

Abstrak: Bencana gempa bumi yang terjadi di berbagai macam kerusakan dan salah satu wilayah yang paling memiliki dampak besar adalah Kabupaten Lombok Utara. Kecamatan Tanjung merupakan salah satu kecampatan yang paling terdampak di Lombok Utara dimana $85 \%$ ba Pemerintah daerah dan pusat beserta beberapa lembaga sosial lainnya saling bekerjasama untuk menyelesaikan permasalahan tempat tinggal masyarakat agar mereka cepat kembali memiliki hunian tempat tinggal yang layak. Sehingga tujuan penelitian ini adalah untuk melihat tingkat efektivitas dari model bangunan rumah yang direkomendasikan oleh pemerintah yaitu Rumah Instan Sehat Sederhana Kayu (RIKA). Metode penel menggunakan 6 variabel dan 14 pertanyaan. Hasil dari penelitian tersebut adalah Risha memiliki nilai efektifitas 3,16, Rika memiliki nilai efektifitas 2,97 dan Riko memiliki nilai 2,99. Dari ketiga model rumah ters masyarakat model Risha memiliki tingkat efektifitas yang paling baik diantara ketiga model rumah yang dibiayai oleh pemerintah namun masih masuk dalam kategori cukup efektif. Sama halnya dengan Rika dan Riko masuk dalam kategori nilai cukup efektif menurut pendapat masyarakat.
\end{abstract}

\begin{abstract}
The earthquake that occurred on the island of Lombok has caused various types of damage and one of the areas that has the greatest impact is North Lombok Regency. Tanjung Subdistrict is one of the most affected sub-districts in North Lombok Regency where $85 \%$ of its residential buildings are leveled with land.Regional and central governments along with several other social institutions work together to solve community housing problems so that they quickly return to having decent dwellings. So the purpose of this study is to look at the effectiveness of the house building models recommended by the government, namely Simple Healthy Instant Houses (RISHA), Convetional Instant Houses (RIKO) and Wood Instant Houses (RIKA). The research method uses linkert analysis using 6 variables and 14 questions. The results of the study are that Risha has an effectiveness value of 3.16, Rika has an effectiveness alue of 2.97 and Rico has a value of 2.99. Of the three house models, the community opinion of the Risha model shows the best level of effectiveness among the three models of houses that are funded by the government but still fall into the fairly effective category. Similarly, Rika and Riko fall into the value category quite effectively in the opinion of the community.
\end{abstract}

\section{A. LATAR BELAKANG}

Gempa bumi yang menguncang pulau Lombok pada hari minggu, 5 Agustus 2018 dengan mangnitudo 7.0 SR disebabkan oleh sesar atau patahan aktif jenis sesar naik pada zona sesar busur belakang flores (Flores Back ARC), salah satu wilayah yang terkena dampak paling parah adalah wilayah Kabupaten Lombok Utara. Kecamatan Tanjung merupakan kecamatan yang terdampak paling parah dimana $85 \%$ atau 13.868 unit tempat tinggal/hunian masyarakat sudah rata dengan tanah (Anonim, 2018). Dampak dari kejadian gempa bumi ini menyebabkan 3.635 unit hunian yang mengalami rusak berat, 3.299 unit mengalami rusak ringan dan 6.934 unit rusak sedang (Anonim, 2018) pusat dan daerah membantu masyarakat untuk memperbaiki hunian mereka, dimana bantuan pembangunan untuk hunian yang mengalami rusak berat sebesar 50 juta, 25 juta untuk rusak sedang dan 15 juta untuk rusak ringan (Prabowo, 2018). Bantuan pemerintah ini akan diberikan dalam model Rumah Instan Sehat Sederhana (Risha), Rumah Instan Konvensional (Riko) dan Rumah Instan Kayu (Rika).

Risha merupakan bentuk teknologi knock down yang digunakan pada bangunan rumah tinggal sederhana sehat, dan telah sesuai dengan Kepmen Kimpraswil No 403/KPTS/M/2003 tentang Pedoman Teknis Rumah Sederhana Sehat. Teknologi Risha yang menggunakan bahan beton bertulang dan tidak banyak mengkonsumsi material dari alam sangat layak dikembangkan karena ramah lingkungan dan memenuhi standar. Keunggulan dari teknologi Risha antara lain: sederhana, cepat, fleksibel, ramah lingkungan, kuat dan durabel serta berkualitas (Sabaruddin \& Sukmana, 2015): 
Model rika menjadi salah satu teknologi rumah tahan gempa dari Kementerian Pekerjaan Umum dan Perumahan Rakyat (PUPR) dengan menggunakan bahan dasar kayu sebagai konstruksinya. Dalam proses pembangunan ini diperlukan kayu rekayasa atau engineering wood yang berasal dari kayu cepat tumbuh seperti sengon. Berdasarkan penelitian yang dilakukan oleh Rinaldi Z, dkk terkait kontruksi tahan gempa bangunan tradisional suku Besemah di Kota Pangaralam, Sumatra Utara tahun 2015 ada 3 prinsip dalam pembangunan rumah kayu tahan gempa yaitu (Rinaldi, Purwantiasning, \& Nur'aini, 2015):

a. Bahan bangunan yang harus seringan mungkin

b. Denah yang sederhana dan simetris, dan

c. Sistem konstruksi yang memadai dalam menguragi resiko gempa.

Model riko merupakan bentuk rumah konvesional yang dibuat mengunakan baja ringan atau pembangunan bisa memanfaatkan sisa-sisa puing bangunan yang tersisa. Rumah riko sendiri termasuk bangunan yang ramah lingkungan dengan biaya pembangunan yang tidak terlau besar, dalam satu unit bangunan riko bisa dikerjakan dengan waktu yang tidak begitu lama. Dimana dalam 1 unit rumah riko bisa dikerjakan selama 2 minggu. Penelitian yang dilakukan oleh (Rinaldi, Purwantiasning, \& Nur'aini, 2015) menyatakan bahwa bahwa rumah konvesional merupakan bagian dari bentuk rumah yang kontruksi bangunannya terbuat dari baja ringan, kayu maupun bahan sisa bangunan yang ada.

Berdasarkan data dari Rekompak Dinas Pekerjaan Umum dan Perumahan Rakyat (PUPR) Provinsi NTB dalam kegiatan rehabilitasi hunian pasca gempa, realisasi pembangunan dan perbaikan rumah yang rusak berat di Kecamatan Tanjung hingga akhir tahun 2018 sampai tahun 2019 dapat dilihat pada tabel berikut (Anonim, 2018).

Tabel 1.

Rehabilitasi Hunian Pasca Gempa Di Kecamatan Tanjung

\begin{tabular}{lcccccc}
\hline \multirow{2}{*}{ Desa } & \multicolumn{3}{c}{ Data Pada Tahun 2018 } & \multicolumn{2}{c}{$\begin{array}{c}\text { Bangunan Yang } \\
\text { Terealisasi Tahun 2018 }\end{array}$} \\
\cline { 2 - 8 } & $\begin{array}{c}\text { Rusak } \\
\text { Berat }\end{array}$ & \multicolumn{3}{c}{$\begin{array}{c}\text { Rehabilitasi } \\
\text { Pasca Gempa }\end{array}$} & \multicolumn{2}{c}{ Jumlah Unit } \\
\cline { 2 - 8 } & & Risha & Rika & Riko & Risha & Rika \\
\hline Jenggala & 262 & 33 & 81 & - & - & - \\
\hline Medana & 777 & 26 & 441 & 92 & - & - \\
\hline Sigar Penjalian & 836 & 8 & 395 & 40 & - & 104 \\
\hline Sokong & 328 & - & 188 & 33 & - & - \\
\hline Tanjung & 439 & 113 & 68 & 42 & 25 & - \\
\hline TegalMaja & 542 & - & 77 & 69 & - & - \\
\hline Teniga & 451 & - & 280 & - & - & - \\
\hline JumlahTotal & 3.635 & 200 & 1.530 & 276 & 25 & 104 \\
\hline
\end{tabular}

Lambannya proses pembangunan hunian ini disebabkan oleh pemerintah mengutamakan pembanguan fasilitas umum seperti : fasilitas perekonomian (pasar), pendidikan, peribadatan dan perkantoran. Sedangkan untuk pembangunan rumah hunian sendiri terkendala oleh bahan bangunan. Hambatan pembangunan model Risha, dimana ketersediaan bahan baku berupa panel beton di Provinsi NTB khususnya di Kecamatan Tanjung masih sangat terbatas. Sama halnya dengan rumah hunian model rika, pembangunannya terkendala bahan baku kayu.

Hingga sampai tahun 2019 ini proses pembangunan rehabilitasi hunian pasca gempa di Kecamatan Tanjung Kabupaten Lombok Utara belum bisa dikerjakan secara maksimal. Berdasarkan kondisi eksisting yang kami dapatkan di lapangan banyak masih banyak bangunan rumah yan belum selesai secara utuh sehingga masih belum dapat ditempati oleh masyarakat. Sehingga tujuan dar penelitian ini adalah untuk menganalisis tingkat efektivitas pembangunan rumah risha, rika dan riko dilihat dari persepsi masyarakat. Sehingga kedepannya dapat dijadikan acuan dalam penanganan pembangunan rumah pasca gempa pada lokasi lainnya.

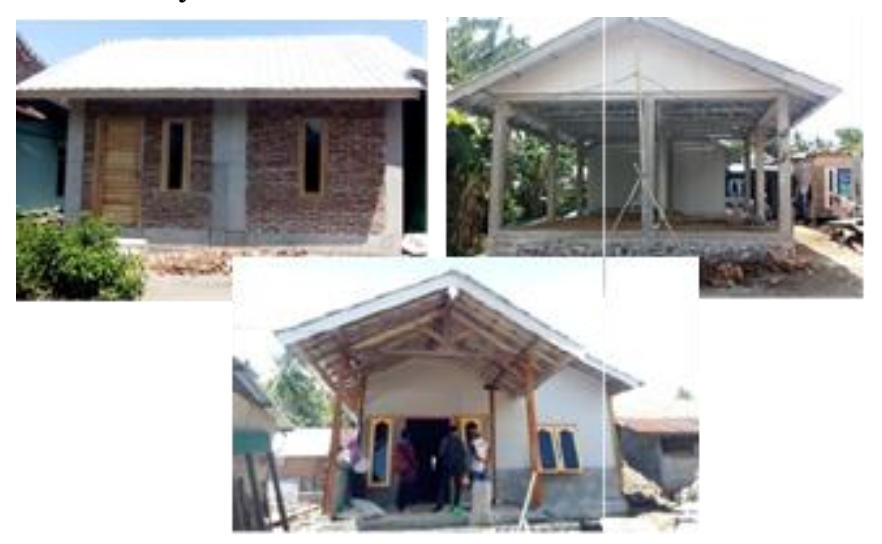

Gambar 1. Kondisi Rumah Risha, Rika, dan Riko di Kecamatan Tajung

\section{B. METODE PENELITIAN}

Penelitian ini menggunakan metode deskriptif kuantitatif dimana hasil dari pengolahan data statistik akan diuraikan secara deskriptif dengan mengkaji dan menganalisis hasil dari kuesioner dan wawancara (Sugiyono, 2016). Variabel penelitian yang digunakan dalam penelitian ini terdiri dari 6 variabel yaitu (Adi, 2016) :

a. Bentuk bangunan

Pertanyaan dari bentuk bangunan antara lain : apakah sudah termasuk dalam bangunan tahan gempa, sudah sesuai keinginan yang diharapkan, dapat memberikan rasa nyaman, bentuk bangunan mempercepat proses rehabilitasi.

b. Bahan bangunan

Pertanyaan dari bahan bangunan antara lain : kelengkapan material, pengambilan material, efektif lokasi pengambilan

c. Waktu pembuatan/pembangunan

Pertanyaan untuk waktu pembuatan berupa target jangka waktu pembangunan?

d. Biaya pembangunan

Pertanyaan dari segi biaya pembangunan antara lain : apakah ada penambahan biaya yang dibebankan kepada penerima bantuan, keterlibatan pokmas / fasilitator dalam pengelolaan biaya pembangunan dan biaya yang diberikan sudah mencukupi.

e. Luas hunian

Pertanyaan dari luas hunian berupa apakah luasan bangunan sesuai dengan harapan.

f. Sistem pengerjaan

Pertanyaan untuk sistem pengerjaan apakah sudah dikerjakan secara swadaya. 
Teknik pengumpulan data penelitian menggunakan teknik sampel kuota (Arikunto, 2010) dimana jumlah kuota yang ditentukan sebanyak 100 sampel. Jumlah sampel 100 ini dipilih secara random untuk 3 kelompok jenis hunian yaitu Risha, Rika dan Riko dengan tetap memperhatikan sebaran hunian pada seluruh desa di Kecamatan Tanjung.

Analisis data menggunakan uji validitas dan reliabilitas data. Uji validitas dilakukan dengan cara menguji korelasi setiap sekor item pertanyaan dengan sekor total kuisioner. Kriteria suatu item pertanyaan dikatakan valid jika nilai korelasinya "positif" dan "lebih besar atau sama dengan $r$ tabel" (rhitung $\geqslant$ rtabel). Dalam perhitungan uji validitas untuk menghitung nilai korelasi digunakan software excel. Sedangkan untuk perhitungan $r$ tabel diperoleh dengan $n=56$ dan $\alpha=5 \%$, yaitu : $\mathrm{r}$ tabel $=0,266$ (Ghozali , 2006). Sedangkan uji reliabilitas dilakukan pengujian dengan menilai data hasil kuisioner yang dapat dipercaya atau reliabel. Karena semua item pertanyaan valid maka, seluruh pertanyaan dicek reliabilitasnya. Data hasil kuisinoer memiliki tingkat reliabiltas tinggi jika nilai koefisien yang diperoleh $\geqslant 0,06$. Nilai reabilitas dari hasil kuisioner hunian risha, rika dan riko bagi masyarakat terdampak gempa di Kecamatan Tanjung dicari mengunakan Teknik Belah Dua (Split- Half Technique), yakitu dengan membagi item pertanyaan ganjil dan genap mengunakan rumus $\mathrm{R}=2 \mathrm{r} / 1+\mathrm{r}$ (Ghozali , 2006).

Teknik analisis yang digunakan analisis skala linkert dimana masing-masing variabel dan pertanyaan akan dinilai dalam lima kelompok penilaian yaitu (Ghozali, 2006):

a. Sangat tidak setuju nilai skor 1

b. Kurang setuju nilai skor 2

c. Cukup setuju skor 3

d. Setuju nilai skor 4

e. Sangat setuju nilai skor 5

Untuk melihat tingkat efektifitas model bangunan dengan menghitung rata-rata nilai dengan masingmasing variabel. Dari hasil penilaian tersebut dibuatkan interval kelas sebanyak 5 (lima), dengan menggunakan rumus sebagai berikut.

$\mathrm{RS}=(\mathrm{m}-\mathrm{n}) / \mathrm{b}$

$\mathrm{RS}=\left(5^{-1}\right) / 5$

$\mathrm{RS}=0,8$

Keterangan:

$\mathrm{RS}=$ Rentang Skala

$\mathrm{m}=$ Angka tertinggi dalam pengukuran

$\mathrm{n}=$ Angka Terendah dalam pengukuran

$\mathrm{b}=$ Banyaknya kelas/kategori yang dibentuk

Sehingga interval penilaian kelasnya sebagai berikut :

a. Jika nilai $1-1,8$ memiliki kategori penilaian sangat tidak efektif

b. Jika nilai $1,8-2,6$ memiliki kategori penilaian kurang efektif

c. Jika nilai 2,6 - 3,4 memiliki kategori penilaian cukup efektif

d. Jika nilai 3,4 - 4,2 memiliki kategori penilaian efektif

e. Jika nilai 4,2 - 5 memiliki kategori penilaian sangat efektif

\section{HASIL DAN PEMBAHASAN}

\section{Uji Validitas dan Reliabilitas Data}

Dari hasil analisis yang dilakukan dalam pengujian validitas dan reliabilitas untuk 14 item pertanyaan dimana memiliki nilai korelasi yang valid dengan hasil yang lebih tinggi dari niai $r$ tabel $(0,195)$ "rhitung $\geqslant$ rtabel, sehingga menunjukkan seluruh item tersebut valid dan tepat untuk digunakan sebagai instrumen angket pertanyaan penelitian. Selain itu juga semua data reliabel karena semuanya memiliki nilai di atas o,6.

\section{Analisis Tingkat Efektivitas}

Tingkat efektifitas dilihat dari beberapa kriteria yaitu dengan melihat tahapan proses pembangunan sehingga masyarakat cepat dapat menggunakan bangunan rumah tersebut dengan tidak menghilangkap prinsip aman terhadap bahaya gempa. Beberapa tahapan proses evaluasi yang juga menjadi variabel penelitian ini merupakan indikator- indikator untuk mengukur tingkat efektifitas model bangunan tahan gempa.

Berdasarkan hasil skoring dan pembobotan yang telah dilakukan pada masing-masing variabel dan item pertanyaan untuk model rumah risha, rika dan riko maka dapat diperoleh nilai-nilai sebagai berikut.

\section{Tabel 2.}

Penilaian Efektivfias Model Bangunan Berdasarkan Pendapat Masyarakat di Kecamatan Tanjung

\begin{tabular}{|c|c|c|c|c|}
\hline No & Item Pertanyaan & RISHA & RIKA & RIKO \\
\hline 1 & $\begin{array}{l}\text { Bangunan termasuk dalam } \\
\text { bangunan tahan gempa }\end{array}$ & 2.29 & 3.56 & 3.59 \\
\hline 2 & $\begin{array}{l}\text { Bangunan sudah sesuai } \\
\text { keinginan yang diharapkan }\end{array}$ & 29 & .04 & $3 \cdot 54$ \\
\hline 3 & $\begin{array}{l}\text { Bangunan memberikan rasa } \\
\text { nyaman }\end{array}$ & 3.50 & 3.53 & $3 \cdot 39$ \\
\hline 4 & $\begin{array}{l}\text { Bangunan memiliki } \\
\text { kelengkapan material yang } \\
\text { baik }\end{array}$ & 3.29 & 2.13 & 2.10 \\
\hline 5 & Rehabilitas hunian cepat & 2.93 & 3.24 & 3.22 \\
\hline 6 & $\begin{array}{l}\text { Kemudahan dalam } \\
\text { pengambilan material } \\
\text { bangunan pada toko }\end{array}$ & 2.64 & 2.09 & 2.07 \\
\hline 7 & Jangka waktu pembangunan & 3.43 & 2.60 & 3.05 \\
\hline 8 & $\begin{array}{l}\text { Bentuk bangunan sesuai } \\
\text { harapan }\end{array}$ & 3.00 & 3.38 & 3.05 \\
\hline 9 & $\begin{array}{l}\text { Bantuan biaya dari } \\
\text { pemerintah sudah } \\
\text { mencukupi }\end{array}$ & 3.57 & 3.36 & 3.24 \\
\hline 10 & $\begin{array}{l}\text { Keterlibatan Pokmas dan } \\
\text { Fasilitator dalam } \\
\text { pengelolaan biaya } \\
\text { pembanguan hunian }\end{array}$ & 3.43 & 2.44 & 1.73 \\
\hline 11 & $\begin{array}{l}\text { Penambahan biaya yang } \\
\text { dibebankan kepada } \\
\text { penerima bantuan }\end{array}$ & 4.07 & 1.96 & 1.90 \\
\hline 12 & $\begin{array}{l}\text { Luas bangunan sudah sesuai } \\
\text { harapan }\end{array}$ & $3 \cdot 36$ & 2.47 & 3.07 \\
\hline 13 & $\begin{array}{l}\text { Proses pembangunan telah } \\
\text { dilakukan secara swadaya }\end{array}$ & 2.79 & 3.44 & $3 \cdot 34$ \\
\hline
\end{tabular}




\begin{tabular}{|c|c|c|c|c|}
\hline 14 & $\begin{array}{l}\text { Kendala dalam proses } \\
\text { pembangunan }\end{array}$ & 2.64 & 4.27 & 4.56 \\
\hline & Nilai Rata-Rata & 3.16 & 2.97 & 2.99 \\
\hline
\end{tabular}

Dari tabel di atas untuk bangunan model risha memiliki nilai 3,16 yang masuk dalam kategori cukup efektif, nilai untuk bangunan rika 2,97 dan riko 2,99 yang juga termasuk dalam kategori cukup efektif. Bangunan risha memiliki tingkat efektif yang lebih tinggi dibandingkan dengan model bangunan lainnya yang ditawarkan oleh pemerintah. Dengan berdasarkan kategori penilaian di atas maka dapat dilihat tingkat efektifitas bangunan dilihat dari variabel dan item pertanyaan diuraikan sebagai berikut.

\section{Hunian Risha}

Menurut pendapat masyarakat untuk bangunan risha yang kurang efektif hanya pada 1 item pertanyaan yaitu: jenis bangunan sudah termasuk dalam bangunan tahan gempa. Sedangkan item pertanyaan lainnya termasuk dalam kategori cukup efektif sampai efektif. Untuk item pertanyaan yang menurut pendapat masyarakat efektif yaitu : bangunan memberikan rasa nyaman kepada penghuninya, terdapat target jangka waktu pembangunan, keterlibatan pokmasa dan fasilitator dalam pengelolaan pembiayaan pembangunan, adanya penambahan biaya yang dibebankan kepada penerima bantuan dan bangunan sudah sesuai dengan harapan masyarakat.

\section{Hunian Rika}

Menurut pendapat masyarakat untuk bangunan rika yang kurang efektif pada item pertanyaan yaitu : kelengkapan material bangunan di lokasi, kesulitan dalam pengambilan material bangunan pada toko-toko, jangka waktu pembangunan, keterlibatan pokmas dan fasilitator dalam pengelolaan biaya, dikenakan biaya tambahan yang dibebankan kepada masyarakat, dan luas bangunan yang tidak sesuai harapan. Penilaian masyarakat untuk kategori cukup efektif pada item pertanyaan : bangunan sudah sesuai dengan keinginan dan harapan, proses rehabilitasi hunian cepat, bentuk bangunan sesuai harapan, dan bantuan biaya dari pemerintah sudah mencukupi. Pendapat masyarakat untuk model rika sudah efektif pada item pertanyaan : bangunan termasuk dalam bangunan tanah gempa dan proses pembangunan telah dilakukan secara swadaya. Sedangkan yang sangt efektif hanya pada proses tidak adanya kendala yang sangat berarti dalam proses pembangunan.

\section{Hunian Riko}

Menurut pendapat masyarakat untuk bangunan riko yang sangat tidak efektif pada pertanyaan keterlibatan pokmasdan fasilitator dalam pengelolaan biaya pembangunan hunian. Untuk penilaian yang tidak efektif pada item pertanyaan : kelengkapan material bangunan di lokasi, kesulitan dalam pengambilan material bangunan pada toko-toko serta adanya penambahan biaya yang dibebankan kepada penerima bantuan. Penilaian masyarakat pembangunan riko cukup efektif pada item pertanyaan: bangunan memberikan rasa nyaman, rehabilitasi hunian cepat, jangka waktu pembangunan, bentuk bangunan sesuai harapan, bantuan biaya dari pemerintah sudha mencukupi, luas bangunan sesuai harapan dan proses pembangunan telah dilakukan secara swadaya. Sedangkan masyakat sudah menilai efektif pada item: bangunan termasuk dalam bangunan tahan gempa dan bangunan sudah sesuai dengan keinginan masyarakat. Sedangkan yang sangt efektif hanya pada proses tidak adanya kendala yang sangat berarti dalam proses pembangunan.

Berdasarkan hasil analisis yang dilakukan maka dapat disimpulkan bahwa untuk jenis hunian yang efektif dalam mempercepat proses rehabilitasi hunian pasca gempa di Kecamatan Tanjung Lombok Utara adalah jenis hunian model risha dibandingkan dengan jenis rumah tahan gempa lainnya. Hasil analisis dan kajian di lapangan beberapa hal yang mendukung model risha menjadi bangunan yang efektif antara lain dilihat dari:

a. Bangunan memiliki kelengkapan material yang baik b. Jangka waktu pembangunan.

c. Bantuan biaya dari pemerintah sudah mencukupi

d. Keterlibatan Pokmas dan Fasilitator dalam pengelolaan biaya pembanguan hunian

e. Penambahan biaya yang dibebankan kepada penerima bantuan

f. Luas bangunan sudah sesuai harapan

Kesemua item di atas dapat memberikan kemudahan dalam proses mempercepat proses pembangunan hunian di Kabupaten Lombok Utara khususnya wilayah Kecamatan Tanjung. Namun meskipun bangunan Risha merupakan bangunan yang efektif dibandingkan dengan model bangunan tahan gempa lainnya yang ditawarkan oleh pemerintah di Kecamatan Tanjung, model bangunan ini masih masuk dalam kriteria cukup efektif. Sehingga hasil temuan kami di lapangan ada beberapa permasalahan yang dialami pada saat proses pembangunan hunian pasca gempa sehingga tidak dapat berjalan efektif. Kajian ini kami bandingkan dengan pembangunan Bale Jajar yang berada di Desa Karang Bajo, Kecamatan Bayan Kabupaten Lombok Utara dimana pembangunan rumah pada Bale Jajar hanya membutuhkan waktu selama 7 hari. Pelaksanaan pembangunan tersebut dilakukan secara swadaya sehingga masyarakat cepat segera dapat menikmati hunian mereka.

\section{SIMPULAN DAN SARAN}

1. Kesimpulan

Kesimpulan dari penelitian hasil penelitian Efektivitas Pembangunan Rumah Risha, Rika dan Riko (3R) Bagi Masyarakat Terdampak Gempa di Kecamatan Tanjung, antara lain: 
a. Efektifitas bangunan rumah tahan gempa yang paling efektif adalah model risha dengan nilai 3,16 sedangkan Rika memiliki nilai efektifitas 2,97 dan Riko memiliki nilai 2,99. Semua model bangunan tahan gempa tersebut masuk dalam kategori cukup efektif.

b. Model risha menjadi bangunan yang lebih efektif dibandingkan dengan model lainnya dilihat dari : bangunan memiliki kelengkapan material yang baik, jangka waktu pembangunan, bantuan biaya dari pemerintah sudah mencukupi, keterlibatan Pokmas dan Fasilitator dalam pengelolaan biaya pembanguan hunian, penambahan biaya yang dibebankan kepada penerima bantuan, dan luas bangunan sudah sesuai harapan.

2. Saran

Dari hasil penelitian yang dilakukan terlihat lambanya proses pembangunan hunian, maka untuk memepercepat proses rehabilitasi hunian bagi masyarakat pemerintah harus memberikan kemudahan bagi masyarakat dengan sistem birokrasi yang tidak ribet dan pengambilan material bangunan tidak ditetapkan pada satu UD/toko bangunan. Memberikan kebebasan bagi masyarakat untuk mengelola dana yang didapatkan dan memberikan kebebasan bagi masyarakat untuk mengabil material pada toko-toko bangunan tetatpi proses pembangunan tetap dibawah pengawasan PUPR. Sehingga dengan cara ini akan dapat mempercepat proses pembangunan hunian bagi masyarakat yang terdampak gempa di Kecamatan Tanjung KLU.

\section{UCAPAN TERIMA KASIH}

1. Terima kasih Kepada kemenristekdiktik yang telah mendanani pproses penelitian yang kami lakukan.

2. Terima kasih Kepada Dosen Pembimbing Baiq Harly Widayant yang selalu mendampingi dan memberikan bimbingan selama proses penelitian berlangsung.

3. Terima kasih kepada wakil rektor kemahasiswaan Universitas Muhammadiya Mataram yang telah memfasilitasi selema proses kegiatan penelitian.

4. Terima kasih kepada LPPM Universitas Muhammadiyah Mataram yang telah membantu mempublikkasikan hasil penelitian yang kami lakukan.

5. Ucapatan terima kasih kepada teman-temen tim peneliti dan teman-teman yang telah membantu kami selama proses penelitian yang tidak kami sebutkan satu persatu.

\section{DAFTAR RUJUKAN}

[1] Adi, A. (2016). Evaluasi Kesesuaian Bangunan Rumah Tinggal Terhadap Aturan Rumah Sederhana Tahan Gempa : Kecamatan Butuh, Kabupaten Perworejo. Jawa Timur: Skripsi Fakultas Teknik Universitas Muhammadiyah Purworejo.
[2] Anonim. (2018). Data Verifikasi Rumah Hunian Pasca Gempa. Kabupaten Lombok Utara: Dinas Pekerjaan Umum Perumahan Rakyat Lombok Utara.

[3] Arikunto, S. (2010). Prosedur Penelitian Suatu Pendekatan Praktik. Jakarta: Rineka Cipta.

[4] Ghozali, I. (2006). Aplikasi Analisis Multivariat dengan Program SPSS, . Semarang: Badan Penerbit Universitas Dipenogoro, 1-7.

[5] Prabowo, D. (2018, Agustus Rabu). Selain Risha, Ada Rika Untuk Korban Gempa Lombok. Kompas.com

[6] Rinaldi, Z., Purwantiasning, A. W., \& Nur'aini, R. D. (2015). Analisa Konstruksi Tahan Gempa Rumah Tradiosional Suku Besemah di Kota Pagaralam Sumtera Selatan. Seminar Naional Sains dan Teknologi (pp. 1-10). Jakarta: Fakultas Teknik Universitas Muhammadiyah Jakarta.

[7] Sabaruddin, A., \& Sukmana, N. P. (2015). RISHA Rumah Instan Sederhana Sehat. Bandung: Kementerian Pekerjaan Umum dan Perumahan Rakyat Pusat Penelitian dan Pengembangan Perumahan dan Permukiman.

[8] Sugiyono. (2016). Metode Penelitian Kuantitatif, Kualitatif dab R\&D. Alfabeta. Bandung, 23. 